\title{
CHEMICAL AND TECHNOLOGICAL STUDIES ON KENAF SEED OIL
}

(Received: 8. 4. 2012)

\author{
By \\ M. E. I. Elsorady, M. A. M. Abd-El-hady and D. M.M. Mostafa \\ Oils and Fats Research Department, Food Tech. Research Institute, \\ Agriculture Research Center, Giza, Egypt
}

\begin{abstract}
This research aimed to study the physical and chemical properties of kenaf seed oil and the suitability for the consumption of foods as well as the edible oils in the frying operation. The frying experiment was conducted on the temperature of $180 \pm 5{ }^{\circ} \mathrm{C}$ for 4 hours daily for five days, using kenaf seed oil compared to cotton oil and palm olein oil and mixtures of these oils with kenaf oil at rates of 10,20 and 30\%. As well as estimateing the proportion of oil uptake in fried potato chips.

The results showed that kenaf seed oil has characteristics close to cotton seed oil during frying process and also had good qualities.
\end{abstract}

Key words: frying, kenaf seed oil, oil uptake of potato, physical and chemical properties.

\section{INTRODUCTION}

Kenaf (Hibiscus cannabinus L. Malvaceae) is a wood to herbaceous plant, mostly unbranched, fast-growing and up to $4.2 \mathrm{~m}$ tall (Reed, 1976). Kenaf is an annual herbaceous African plant, but also well known in other geographical areas of the world (Chifundera et al., 1994).

Kenaf is a warm season annual crop closely related to cotton (Gossypium barbadense L. Malvaceae), and okra (Abelmoschus esculentus L. Malvaceae) (Webber et al., 2002).

Kenaf is one of the most important fiber crops in the world (Charles et al., 2002) .

Kenaf is cultivated secondarily for the seeds which contain about $20 \%$ oil, used for: salad, cooking and lubricant oils. Kenaf oil is also used in the manufacture of soap, linoleum, paints and varnishes (Ather and Mahmood, 2005).

Edible fats and oils play an important role in human health and nutrition because they are important source of energy, essential fatty acids and fat-soluble vitamins.

The most important industrial and domestic application of vegetable oils is their use in the frying food processes. Frying is a cooking and particularly a process in terms of working temperature where oil is heated in the presence of air and light at temperatures ranging from $160^{\circ} \mathrm{C}$ to $200^{\circ} \mathrm{C}$ for periods of time relatively long. During the frying process, oils are continuously exposed to several factors that lead to a large diversity of chemical reactions, such as, hydrolysis, oxidation and polymerization of the triacylglycerol molecule (Gião, 1999).

Frying of foods is one of the most common and popular practices in their preparation and manufacture (Gil et al., 2004). It is a fast, convenient, and energy-efficient cooking method and increases palatability due to fat absorption, crust formation, and pleasant flavors and odors (Varela and Ruiz-Roso, 1992). However, it is well known that frying oils used continuously at high temperatures in the presence of oxygen and water from the food being fried, are subject to thermal oxidation, polymerization, and hydrolysis, and the resultant decomposition products adversely affect flavor and color (Clark and Serbia, 1991; White, 1991; and Tyagi, and Vasishtha, 1996). In addition, undesirable constituents produced from degraded frying oils may even be harmful to health (Innawong et al., 2004).

Our objectives were to assess the performance of kenaf seed oil and its use for deep-fat frying of foods and to compare its performance and stability to commercial cotton seed oil and palm olein oil and their blending with kenaf seed oil. We compared kenaf seed oil to cotton seed oil, in order to cover the gap of oil production, and also compared kenaf seed oil to palm olein oil, which is commonly used in the world.

\section{MATERIALS AND METHODS}




\subsection{Materials}

Seeds of kenaf (Hibiscus cannabinus L.) (Giza 3) were brought from the Fiber Crop Department, Field Crops Research Institute, Agricultural Research Center, Giza, Egypt.

Cotton seed oil was obtained from Tanta Oil \& Soap Company, Tanta, Egypt.

Palm-olein oil was obtained from Alexandria Oils and Soap Company (AOSCO), Alexandria, Egypt. Palm-olein oil was used in this study because of its major commercial role in deep-fat frying (Rasit and Augustin, 1982).

\subsubsection{Potatoes}

Potatoes (Solanum tuberosum, L.) were purchased from a local market, Desouk, Egypt.

\subsubsection{Preparation of potato chips}

Potatoes were peeled, cut into 2-mm thick slices using a mechanical slicer, washed and dried prior to frying.

Oil blends were prepared by mixing 70,80 , and $90 \%$ cotton seed oil or palm olein oil with $30,20,10 \%$, kenaf seed oil, respectively. The pure kenaf seed oil, cotton seed oil, olein oil and their blends were used to fry potato slices. The frying process was done in glass cups at $180 \pm 5$ ${ }^{\circ} \mathrm{C}$ until oils form foams.

\subsection{Methods}

\subsubsection{Chemical analysis of kenaf seeds}

\subsubsection{Moisture content}

Moisture content was determined by drying kenaf seeds in an oven at $105{ }^{\circ} \mathrm{C}$ until a constant weight (A.O.A.C, 2005).

\subsubsection{Fat content}

Oil content of kenaf seeds was determined by means of the Soxhelt fat extraction apparatus using hexane of $60-80^{\circ} \mathrm{C}$ boiling point as described by A.O.A.C. (2005).

\subsubsection{Crude protein content}

The crude protein was determined using micro Kjeldahl method as described in A.O.A.C. (2005).The percentage of nitrogen was then multiplied by 6.25 to give the crude protein level of kenaf seeds.

\subsubsection{Ash content}

Ash was determined by the AOAC method (A.O.A.C., 2005). Kenaf seeds, approximately $1.5 \mathrm{~g} / \mathrm{batch}$, were ashed in a porcelain crucible. This was transferred into a muffle furnace set at $550{ }^{\circ} \mathrm{C}$ and left for about 6 hours. The ashed material was weighed and the percentage of ash was calculated.

\subsubsection{Total carbohydrate}

The total carbohydrate of kenaf seeds was calculated by difference, i.e. subtracting the sum of the moisture, oil, protein and ash levels from
100 (James, 1995).

\subsubsection{Extraction of kenaf seed oil}

The oil from kenaf seed was extracted through solvent extraction technique as described in AOCS (1998); hexane used as solvent was recovered by Rotary Evaporator Apparatus. The extracted oil was stored in dark brown glasses at $\left(-20^{\circ} \mathrm{C}\right)$ until used.

\subsubsection{Physico-chemical analyses of the studied oils}

\subsubsection{Free Fatty Acids (FFA's)}

The FFA's of the investigated samples were examined according to the method described in the AOCS Official method No. Ca 5a-40 (1998) and were calculated in terms of free fatty acids percentage as oleic acid.

\subsubsection{Peroxide value (P.V.)}

This characteristic was tested according to the AOCS Official method Cd8-53 (1998). The peroxide value was reported as milli-equivalents of peroxide per kilogram sample (meq $\mathrm{O}_{2} / \mathrm{kg}$ oil).

\subsubsection{Thiobarbituric acid (T.B.A.)}

TBA number of the oil was determined according to Allen and Hamilton (1989). The TBA value calculated as mg malonaldehyde $/ \mathrm{kg}$ oil.

\subsubsection{Total polar compounds (T.P.C.)}

Total polar compounds (\%) of the oils was determined by silica column chromatography, following the method proposed by Dobarganes et al. (1988), with the following modification: an accurately weighed sample of $1.00 \pm 0.01 \mathrm{~g}$ of each oil was dissolved in $20 \mathrm{ml}$ hexane/ diethyl ether 90/10 (vol./ vol.). The same proportion of hexane/diethyl ether was used to fill the column and to elute the nonpolar fraction, to obtain a sharper separation (Dobarganes et al., 1988; Cuesta et al., 1991).

\subsubsection{Smoke point}

Smoke point was determined according to the Method No. Cc 9a-48 (AOCS, 1998). Smoke point is the temperature when oil captures smoke.

\subsubsection{Gas chomatography analysis of fatty acid composition \\ 2.2.3.6.1. Methylation of fatty acids}

An aliquot of fatty acids, about $10 \mathrm{mg}$, was dissolved in $2 \mathrm{ml}$ hexane and then $0.4 \mathrm{ml} \mathrm{Zn}$ $\mathrm{KOH}$ in anhydrous methanol was added (Cossignani et al., 2005), after $3 \mathrm{~min}, 3 \mathrm{ml}$ water was added. The organic layer, separated by centrifugation, was dried over anhydrous sodium sulfate, and then concentrated, with a $\mathrm{N}_{2}$ stream to around $0.5 \mathrm{ml}$ for $\mathrm{GC}$ analysis of fatty acids methyl esters (FAME) as described below. 


\subsection{GC analysis of fatty acid methyl esters}

Agilent 6890 series GC apparatus provided with a DB-23 column $(60 \mathrm{~m} \times 0.32 \mathrm{~mm} \times 0.25$ $\mu \mathrm{m})$ was used. Fatty acids resulted after the previous procedures were transformed into methyl esters and directly injected into the GC.

\subsubsection{Oil-uptake}

Oil-uptake of the potato sample was determined according to Pinthus et al. (1993). It is expressed as $\mathrm{g} / 100 \mathrm{~g}$ dry matter, excluding oil.

\section{RESULTS AND DISCUSSION \\ 3.1. Chemical analysis of kenaf seeds}

Data in Table (1) show the chemical composition of Kenaf seeds. Data revealed that kenaf seeds had $10.9 \%$ moisture and contain as percentages of 28.9, 34.9, 7.8 and 28.4 for fat, crude protein, ash and carbohydrates, on dry bases, respectively. These results are close to those results of El-Daly (1970), Mohamed et al. (1995) and Hussein et al. (2006).

Table (1): Chemical composition of kenaf seeds (\%).

\begin{tabular}{|l|c|}
\hline \multicolumn{1}{|c|}{ Chemical composition } & $\%$ \\
\hline Moisture & 10.9 \\
\hline Fat & $28.9 *$ \\
\hline Crude protein & $34.9 *$ \\
\hline Ash & $\mathbf{7 . 8}^{*}$ \\
\hline Carbohydrates & $28.4^{*}$ \\
\hline * On dry basis
\end{tabular}

\subsection{Changes in the studied oils and their blends during frying process \\ 3.2.1. Free Fatty Acids (FFA's\%)}

An increase in FFA's was observed during frying in all the oils. The increase in FFA's could be attributed to oxidation and hydrolysis, which produce FFA's (Peeled et al., 1975; Abdel-Aal and Karara 1986).

Concerning the acidity of kenaf seed oil, cottonseed and olein oil samples and their blends; the obtained results in Table (2) and Figure (1) showed that acidity increased gradually in all oil samples during frying at 180 ${ }^{\circ} \mathrm{C}$. However, the rate of increase was dependent on oil type, and the percentage of blend. Generally, it can be observed from the results in Table (2) and Figure (1) that kenaf oil had the highest initial acidity $(0.49 \%)$ among the studied oils. On the other hand, olein oil had the lowest initial FFA $(0.19 \%)$.

The initial free fatty acid value of KO (kenaf oil) was seen to be (0.49), which increased to
(1.42) after 9 hours. The free fatty acid value of $\mathrm{CO}$ (cotton oil) increased from 0.24 to $0.58 \%$ after 10 hours of frying at $180 \pm 5^{\circ} \mathrm{C}$. Also, the data revealed that the free fatty acid value of $\mathrm{OO}$ (olien oil) increased from 0.19 to $0.4 \%$ after 18 hrs of frying at $180 \pm 5^{\circ} \mathrm{C}$.

The free fatty acid values of kenaf seed oil blended with cotton seed oil in Table (2) and Figure (1) were seen to range from 0.3 to 0.74 in $\mathrm{CO}+10 \% \mathrm{KO}$ blend and 0.35 to 0.87 in the $\mathrm{CO}+20 \% \mathrm{KO}$ blend and 0.39 to $0.98 \%$ in $\mathrm{CO}+30 \% \mathrm{KO}$ blend after $10 \mathrm{hrs}$ of frying at $180 \pm 5^{\circ} \mathrm{C}$. The free fatty acid values of kenaf seed oil blended with olein oil were seen to range from 0.24 to $0.55 \%$ in $\mathrm{OO}$ (olien oil) $+10 \% \mathrm{KO}$ (kenaf oil) blend after $16 \mathrm{hrs}$ of frying at $180 \pm 5{ }^{\circ} \mathrm{C}$ and from 0.29 to $0.74 \%$ in the $\mathrm{OO}+20 \% \mathrm{KO}$ blend and from 0.32 to $0.86 \%$ in $\mathrm{OO}+30 \% \mathrm{KO}$ blend after $14 \mathrm{hrs}$ of frying at $180 \pm 5^{\circ} \mathrm{C}$.

\subsubsection{Peroxide value (P.V)}

The extent of oil oxidation has been frequently evaluated by measuring peroxide values (PVs) (Melton et al., 1994). The data presented in Table (2) and Figure (2) showed that the changes took place in peroxide value (P.V) of kenaf seed, cottonseed, olein oils and their blends due to frying at $180 \pm 5{ }^{\circ} \mathrm{C}$.. Generally, it was noticed that the P.V. values were increased gradually in all oil samples during frying.

The PV is related to the hydroperoxides, the primary oxidation products, which are unstable under deep-fat frying conditions and readily decompose into mixtures of mainly volatile aldehyde compounds. Concentrations of the oxidation product, expressed in PV, may increase after the sample is withdrawn from the fryer, thus PV may not indicate the actual extent of oil deterioration (Fritch, 1981; Gutirrez et al., 1988; Melton et al., 1994).

The changes in the peroxide values of the studied oils and their blends during frying at $180 \pm 5^{\circ} \mathrm{C}$ are seen in Table 2 . It was observed that the increase in PV of $\mathrm{KO}$ was from 0.9 to $15.11 \mathrm{meqO}_{2} / \mathrm{kg}$ oil, during $9 \mathrm{hrs}$ of frying at $180 \pm 5^{\circ} \mathrm{C}$. The PV value of $\mathrm{CO}$ increased from 1.0 to $14.18 \mathrm{meqO}_{2} / \mathrm{kg}$ oil, after 10 hours of frying at $180 \pm 5^{\circ} \mathrm{C}$. Also, the data revealed that $\mathrm{PV}$ of $\mathrm{OO}$ increased from 0.75 to 11.02 $\mathrm{meqO}_{2} / \mathrm{kg}$ oil, after $18 \mathrm{hrs}$ of frying at $180 \pm 5^{\circ} \mathrm{C}$. The PV values of kenaf seed oil blended with cotton seed oil in Table (2) and Figure (2) were seen to range from 1 to $14.41 \mathrm{meq} \mathrm{O}_{2} / \mathrm{kg}$ oil ( in $\mathrm{CO}+10 \% \mathrm{KO}$ blend ), from 1.0 to 14.63 

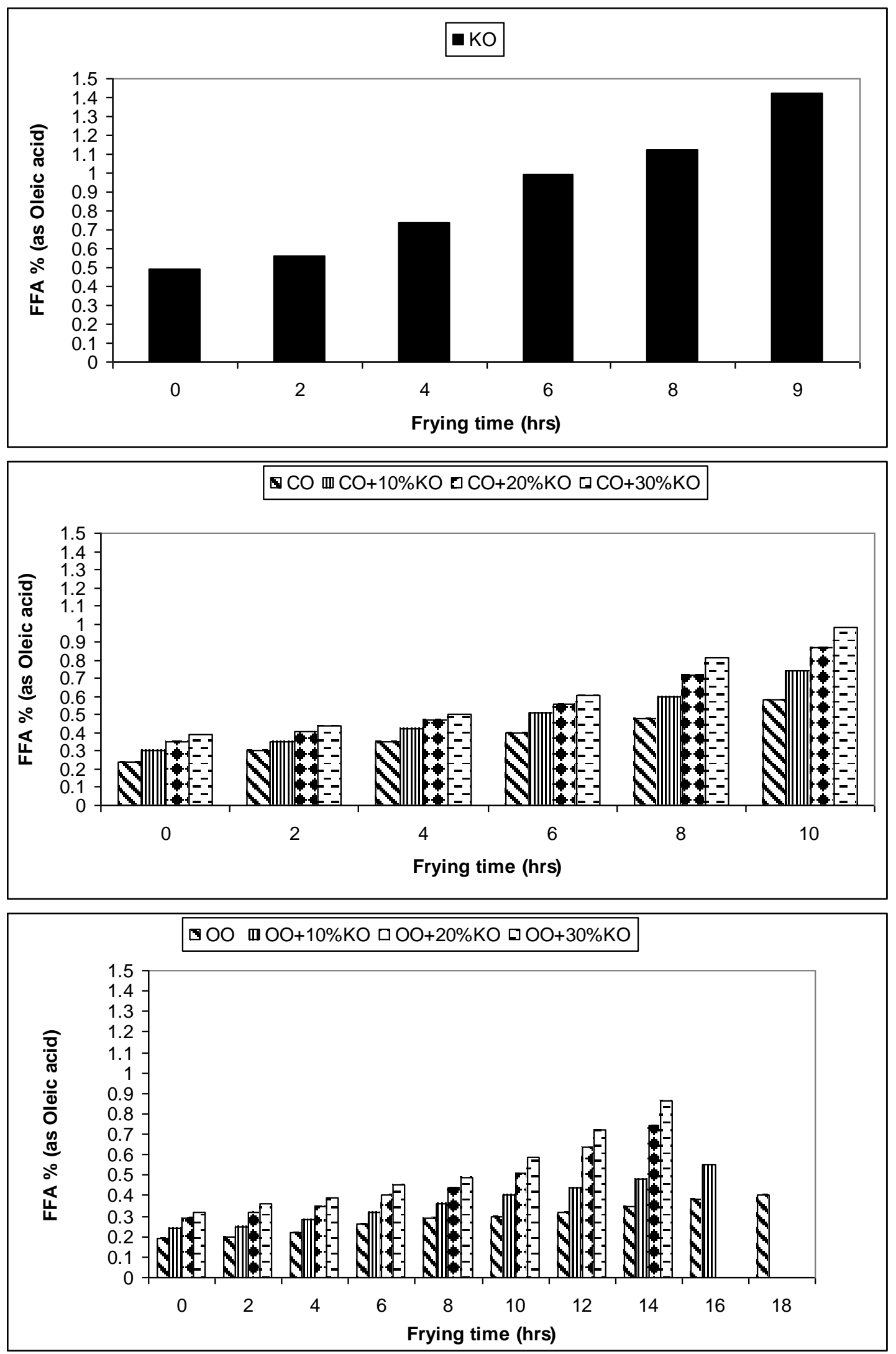

Fig. (1): Effect of frying time on free fatty acids (FFA's\%) of the studied oils. (Kenaf seed oil $=\mathrm{KO}$, Cotton seed oil $=\mathrm{CO}$, Olein oil $=0 O)$. 

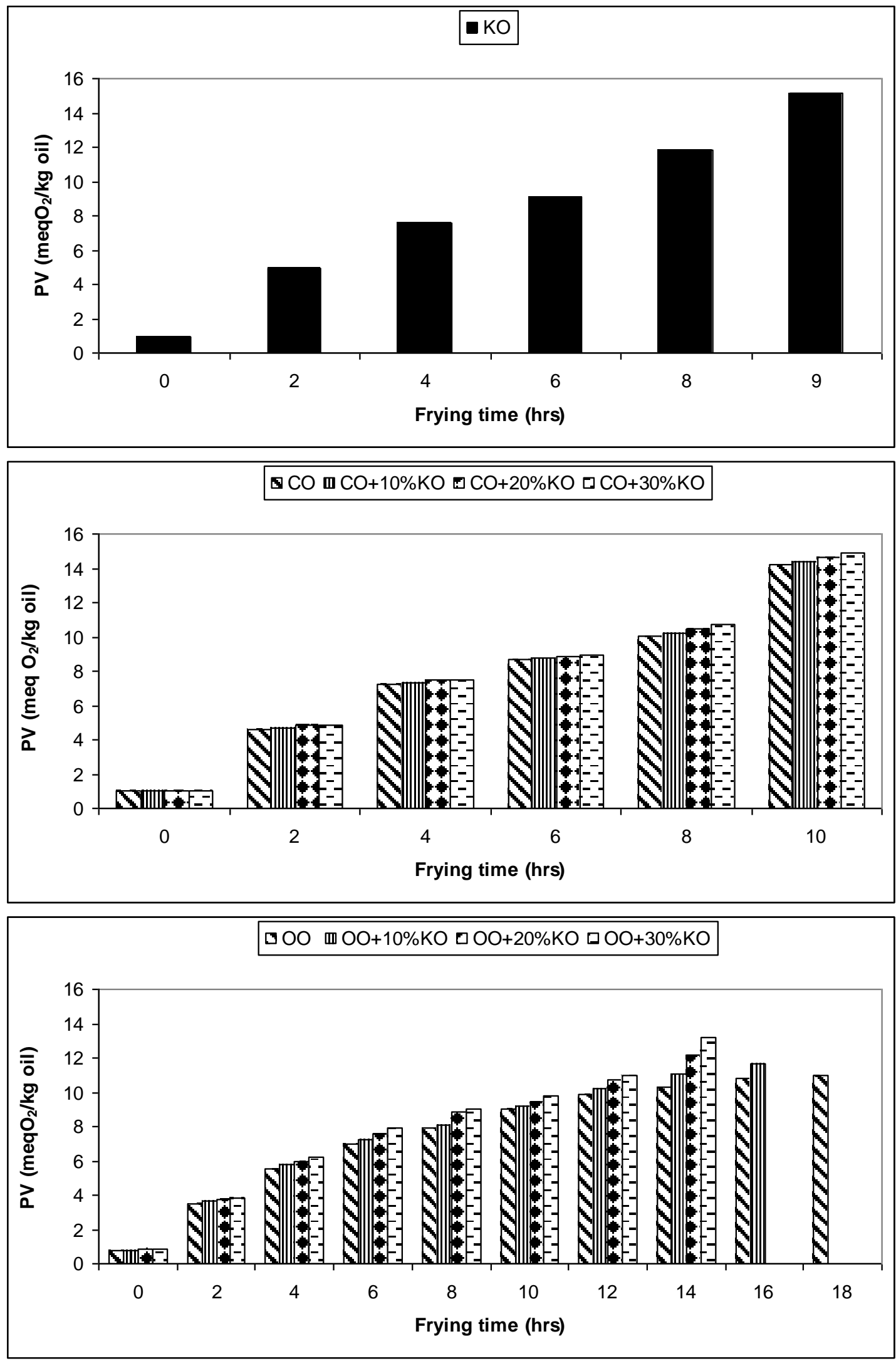

Fig. (2): Effect of frying time on peroxide value of the studied oils. (Kenaf seed oil = KO, Cotton seed oil $=$ CO, Olein oil $=0 O)$. 


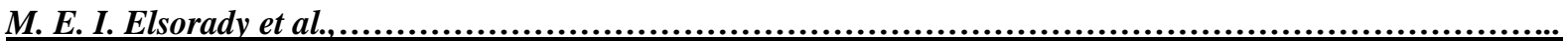

Table (2): Effect of frying time on free fatty acids and peroxide values of the studied oils.

\begin{tabular}{|c|c|c|c|c|c|c|c|c|c|}
\hline \multirow{3}{*}{$\begin{array}{c}\text { Frying } \\
\text { time } \\
\text { (hrs) }\end{array}$} & $\begin{array}{l}\text { Kenaf } \\
\text { oil (KO) }\end{array}$ & \multicolumn{4}{|c|}{ Cotton seed oil $(\mathrm{CO})$} & \multicolumn{4}{|c|}{ Olein oil (OO) } \\
\hline & KO & $\mathrm{CO}$ & $\mathbf{A}^{*}$ & B* & $\mathbf{C}^{*}$ & OO & $\mathbf{D} * *$ & $\mathbf{E}^{* *}$ & $\mathbf{F}^{* *}$ \\
\hline & \multicolumn{9}{|c|}{ Free fatty acids (FFA) (\% as oleic acid) } \\
\hline $\mathbf{0}$ & 0.49 & 0.24 & 0.30 & 0.35 & 0.39 & 0.19 & 0.24 & 0.29 & 0.32 \\
\hline 2 & 0.56 & $\mathbf{0 . 3 0}$ & 0.35 & 0.41 & 0.44 & 0.20 & 0.25 & 0.32 & 0.36 \\
\hline 4 & 0.74 & 0.35 & 0.42 & 0.47 & $\mathbf{0 . 5 0}$ & 0.22 & 0.28 & 0.35 & 0.39 \\
\hline 6 & 0.99 & 0.40 & 0.51 & 0.56 & 0.61 & 0.26 & $\mathbf{0 . 3 2}$ & 0.40 & 0.45 \\
\hline 8 & 1.12 & 0.48 & 0.60 & 0.72 & 0.81 & 0.29 & 0.36 & 0.44 & 0.49 \\
\hline 9 & 1.42 & & & & & & & & \\
\hline 10 & & $\mathbf{0 . 5 8}$ & 0.74 & 0.87 & 0.98 & $\mathbf{0 . 3 0}$ & 0.4 & 0.51 & 0.59 \\
\hline 12 & & & & & & 0.32 & 0.44 & 0.64 & 0.72 \\
\hline 14 & & & & & & 0.35 & 0.48 & 0.74 & 0.86 \\
\hline 16 & & & & & & 0.38 & 0.55 & & \\
\hline \multirow[t]{2}{*}{18} & & & & & & 0.40 & & & \\
\hline & \multicolumn{9}{|c|}{ Peroxide value (PV) ( meq $\mathrm{O}_{2} / \mathrm{kg}$ oil) } \\
\hline $\mathbf{0}$ & 0.90 & 1.00 & 1.00 & 1.00 & 1.00 & 0.75 & 0.79 & 0.82 & 0.88 \\
\hline 2 & 4.95 & 4.61 & 4.72 & 4.84 & 4.89 & 3.51 & 3.69 & 3.75 & 3.87 \\
\hline 4 & 7.55 & 7.21 & 7.33 & 7.48 & 7.50 & 5.52 & 5.78 & 5.98 & 6.21 \\
\hline 6 & 9.10 & 8.65 & 8.74 & 8.84 & 8.96 & 7.01 & 7.20 & 7.61 & 7.90 \\
\hline 8 & 11.80 & 10.02 & 10.24 & 10.45 & 10.75 & 7.90 & 8.10 & 8.87 & 9.04 \\
\hline 9 & 15.11 & & & & & & & & \\
\hline 10 & & 14.18 & 14.41 & 14.63 & 14.90 & 8.98 & 9.23 & 9.44 & 9.78 \\
\hline 12 & & & & & & 9.87 & 10.24 & 10.73 & 11.01 \\
\hline 14 & & & & & & 10.30 & 11.07 & 12.21 & 13.21 \\
\hline 16 & & & & & & 10.77 & 11.70 & & \\
\hline 18 & & & & & & 11.02 & & & \\
\hline
\end{tabular}

$* \mathrm{~A}=\mathrm{CO}+10 \% \mathrm{KO}, \mathrm{B}=\mathrm{CO}+20 \% \mathrm{KO}$ and $\mathrm{C}=\mathrm{CO}+30 \% \mathrm{KO}$

$\mathrm{meqO}_{2} / \mathrm{kg}$ oil (in the $\mathrm{CO}+20 \% \mathrm{KO}$ blend) and from 1.0 to $14.9 \mathrm{meqO}_{2} / \mathrm{kg}$ oil (in $\mathrm{CO}+30 \% \mathrm{KO}$ blend), after $10 \mathrm{hrs}$ of frying at $180 \pm 5^{\circ} \mathrm{C}$. The PV values of kenaf seed oil blended with olein oil were seen to range from 0.79 to 11.7 $\mathrm{meqO}_{2} / \mathrm{kg}$ oil (in $\mathrm{OO}+10 \% \mathrm{KO}$ blend), after 16 hrs of frying at $180 \pm 5{ }^{\circ} \mathrm{C}$; from 0.82 to 12.21 $\mathrm{meqO}_{2} / \mathrm{kg}$ oil (in the $\mathrm{OO}+20 \% \mathrm{KO}$ blend) and from 0.88 to $13.21 \mathrm{meqO}_{2} / \mathrm{kg}$ oil (in $\mathrm{OO}+30 \%$ $\mathrm{KO}$ blend) after $14 \mathrm{hrs}$ of frying at $180 \pm 5^{\circ} \mathrm{C}$.

On the other hand, the spoilage of either cottonseed oil or kenaf oil was considered to have occurred when the peroxide value surpassed $10 \mathrm{meq} / \mathrm{Kg}$ oil according to Codex (2004).

\subsubsection{Thiobarbituric acid (TBA)}

The results in Table (3) and Figure (3) revealed that TBA values were increased during frying at $180 \pm 5^{\circ} \mathrm{C}$. Same trend like FFA and PV was observed in TBA values.

In addition, the increase in TBA value due to increasing in absorption at $532 \mathrm{~nm}$ could reflect the increases in shorter chain dienals and malonaldehydes, which are not as pleasant in flavor (Jacobson, 1967).
$* * \mathrm{D}=0 \mathrm{OO}+10 \% \mathrm{KO}, \mathrm{E}=\mathbf{O O}+20 \% \mathrm{KO}$ and $\mathrm{F}=\mathbf{O O}+30 \% \mathrm{KO}$

Thiobarbituric acid (TBA) values of $\mathrm{KO}, \mathrm{CO}$, $\mathrm{OO}$ and the blends are displayed in Table 3 and Figure (3); an increase in TBA values could be noticed between the initial and final point in the oils and their blends. The value ranged from 0.1 to $1.55 \mathrm{mg}$ malonaldehyde / $\mathrm{kg}$ oil in $\mathrm{KO}$ after 9 hrs of frying. The data showed that TBA value of $\mathrm{CO}$ increased from 0.1 to $1.34 \mathrm{mg}$ malonaldehyde / $\mathrm{kg}$ oil after $10 \mathrm{hrs}$ of frying and TBA value of OO increased from 0.06 to $1.12 \mathrm{mg}$ malonaldehyde / $\mathrm{kg}$ oil after $16 \mathrm{hrs}$ of frying.

The data in Table (3) and Figure (3) showed that, all cotton seed oil blends with kenaf oil recorded an initially value of $0.1 \mathrm{mg}$ malonaldehyde / $\mathrm{kg}$ oil and finally values, after $10 \mathrm{hrs}$ of frying, of $1.42,1.48$ and $1.50 \mathrm{mg}$ malonaldehyde $/ \mathrm{kg}$ oil for $\mathrm{CO}+10 \% \mathrm{KO}, \mathrm{CO}+$ $20 \% \mathrm{KO}, \mathrm{CO}+30 \% \mathrm{KO}$, respectively. TBA value of $\mathrm{OO}+10 \% \mathrm{KO}$ ranged from 0.06 to $1.16 \mathrm{mg}$ malonaldehyde / $\mathrm{kg}$ oil after $16 \mathrm{hrs}$ of frying. Also, TBA values of $\mathrm{OO}+20 \% \mathrm{KO}$ and $\mathrm{OO}+30 \%$ $\mathrm{KO}$ ranged from 0.08 and 0.08 to 1.56 and 1.59 $\mathrm{mg}$ malonaldehyde / $\mathrm{kg}$ oil, respectively, after 14 hrs of frying. The results of the present study are in agreement with those of Sati et al. (2011). 

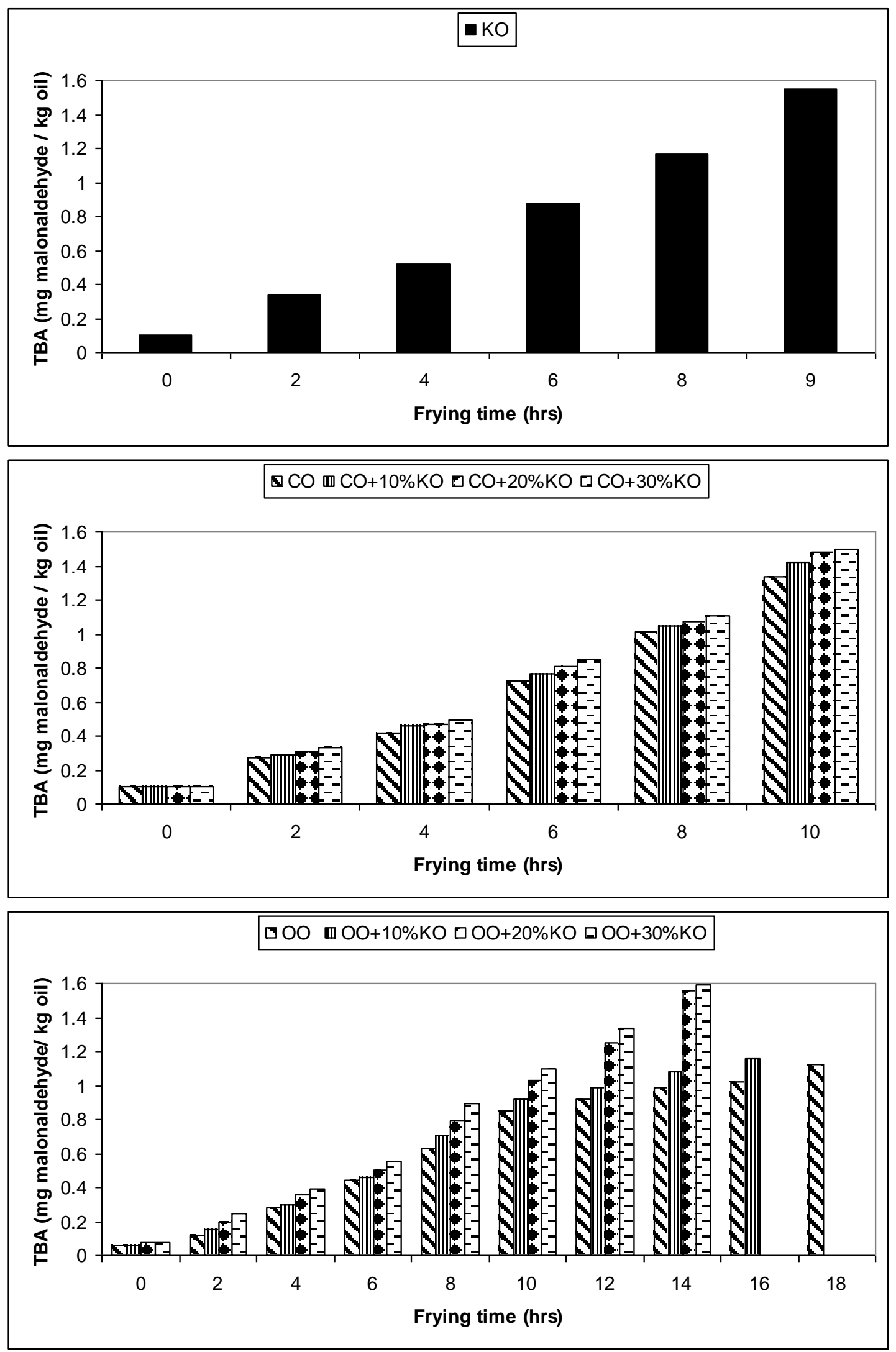

Fig. (3): Effect of frying time on TBA number of the studied oils. (Kenaf seed oil = KO, Cotton seed oil = CO, Olein oil $=$ OO). 


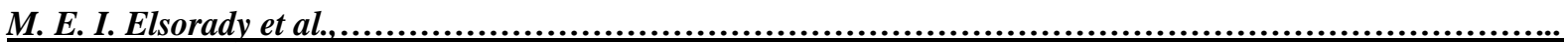

Table (3): Effect of frying time on TBA number and total polar compounds of the studied oils.

\begin{tabular}{|c|c|c|c|c|c|c|c|c|c|}
\hline \multirow{3}{*}{$\begin{array}{c}\text { Frying } \\
\text { time (hrs) }\end{array}$} & \multirow{2}{*}{$\begin{array}{c}\text { Kenaf oil } \\
(\mathrm{KO})\end{array}$} & \multicolumn{4}{|c|}{ Cotton seed oil (CO) } & \multicolumn{4}{|c|}{ Olein oil $(\mathbf{O O})$} \\
\hline & & CO & $\mathbf{A}^{*}$ & B* & $\mathbf{C}^{*}$ & $\mathbf{O O}$ & $\mathbf{D} * *$ & $\mathbf{E}^{* *}$ & $\mathbf{F}^{* *}$ \\
\hline & \multicolumn{9}{|c|}{ TBA number (mg malonaldehyde / kg oil) } \\
\hline $\mathbf{0}$ & 0.10 & 0.10 & $\mathbf{0 . 1 0}$ & 0.10 & 0.10 & 0.06 & 0.06 & $\mathbf{0 . 0 8}$ & $\mathbf{0 . 0 8}$ \\
\hline 2 & 0.34 & 0.27 & 0.29 & 0.31 & $\mathbf{0 . 3 3}$ & 0.12 & 0.15 & $\mathbf{0 . 2 0}$ & $\mathbf{0 . 2 5}$ \\
\hline 4 & $\mathbf{0 . 5 2}$ & $\mathbf{0 . 4 2}$ & 0.46 & 0.47 & 0.49 & 0.28 & $\mathbf{0 . 3 0}$ & 0.36 & $\mathbf{0 . 3 9}$ \\
\hline 6 & $\mathbf{0 . 8 8}$ & 0.72 & 0.77 & 0.81 & 0.85 & 0.44 & 0.46 & 0.50 & 0.55 \\
\hline 8 & 1.17 & 1.01 & 1.05 & 1.07 & 1.11 & 0.63 & 0.71 & $\mathbf{0 . 7 9}$ & $\mathbf{0 . 8 9}$ \\
\hline 9 & 1.55 & & & & & & & & \\
\hline 10 & & 1.34 & 1.42 & 1.48 & 1.50 & 0.85 & 0.92 & $\mathbf{1 . 0 3}$ & 1.10 \\
\hline 12 & & & & & & 0.92 & 0.99 & 1.25 & 1.34 \\
\hline 14 & & & & & & 0.99 & 1.08 & 1.56 & 1.59 \\
\hline 16 & & & & & & 1.02 & 1.16 & & \\
\hline \multirow[t]{2}{*}{18} & & & & & & 1.12 & & & \\
\hline & \multicolumn{9}{|c|}{ Total polar compounds (TPC \%) } \\
\hline $\mathbf{0}$ & 8.30 & 6.10 & 6.60 & 7.10 & 7.60 & 4.30 & 4.99 & 5.25 & 5.47 \\
\hline 9 & 28.21 & & & & & & & & \\
\hline 10 & & 26.21 & 26.78 & 27.24 & 27.85 & & & & \\
\hline 14 & & & & & & & & 27.6 & 27.66 \\
\hline 16 & & & & & & & 28.92 & & \\
\hline 18 & & & & & & 27.95 & & & \\
\hline
\end{tabular}

\subsubsection{Polar Compounds}

The amount of polar compounds is considered one of the most reliable criteria for the assessment of frying oils for human consumption. Research has shown that the fraction of polar compounds isolated from oxidized oil is most toxic to laboratory animals (Pantzaris, 1998). Therefore, in several European countries maximum values between 24 and $27 \%$ are set for commercial used frying oils. Table (3) shows the results of the determination of the polar compounds in the studied oils during frying. The amount of polar compounds increased drastically for oils during successive frying. The data showed that the amount of polar compounds for olein oil increased from $4.3 \%$ as initial value to $27.95 \%$ after $18 \mathrm{hrs}$ of frying. In the case of Kenaf seed oil, the amount of polar compounds increased quickly from $8.3 \%$ as initial value to 28.21 after 9 hours of frying. This means that kenaf seed oil little exceeded the limit for polar compounds already after 9 hours.

The obtained results in Table (3) showed also that using these frying oils had reached the end of their useful frying life after 9 hrs for kenaf seed oil (KO), $10 \mathrm{hrs}$ for cotton seed oil (CO), $\mathrm{CO}+10 \% \mathrm{KO} ; \mathrm{CO}+20 \% \mathrm{KO}$ and $\mathrm{CO}+30 \% \mathrm{KO}$ of intermittent frying. On the other side, Olien oil (OO) discarded after 18 hrs; 16 hrs for $\mathrm{CO}+10 \% \mathrm{KO}$ and $14 \mathrm{hrs}$ for both of $\mathrm{CO}+20 \% \mathrm{KO}$ and $\mathrm{CO}+30 \% \mathrm{KO}$. The determination of the total hours of frying before the polar compounds reach the $27 \%$ critical level mark was carried out using the linear equation, which is more adequate because there was no replenishment with fresh oil, and the polar compounds kept increasing until the end of the frying (Tsakins and Lalas 2002).

\subsubsection{Smoke point}

Table (4) and Figure (4) show the changes in the smoke point of the studied oils during frying. The amount of smoke emanating from a cup is directly proportional to the concentration of low molecular weight decomposition products in the oil. Free fatty acids and other volatile compounds evaporating from the fat will not appear as smoke until their concentration is high 

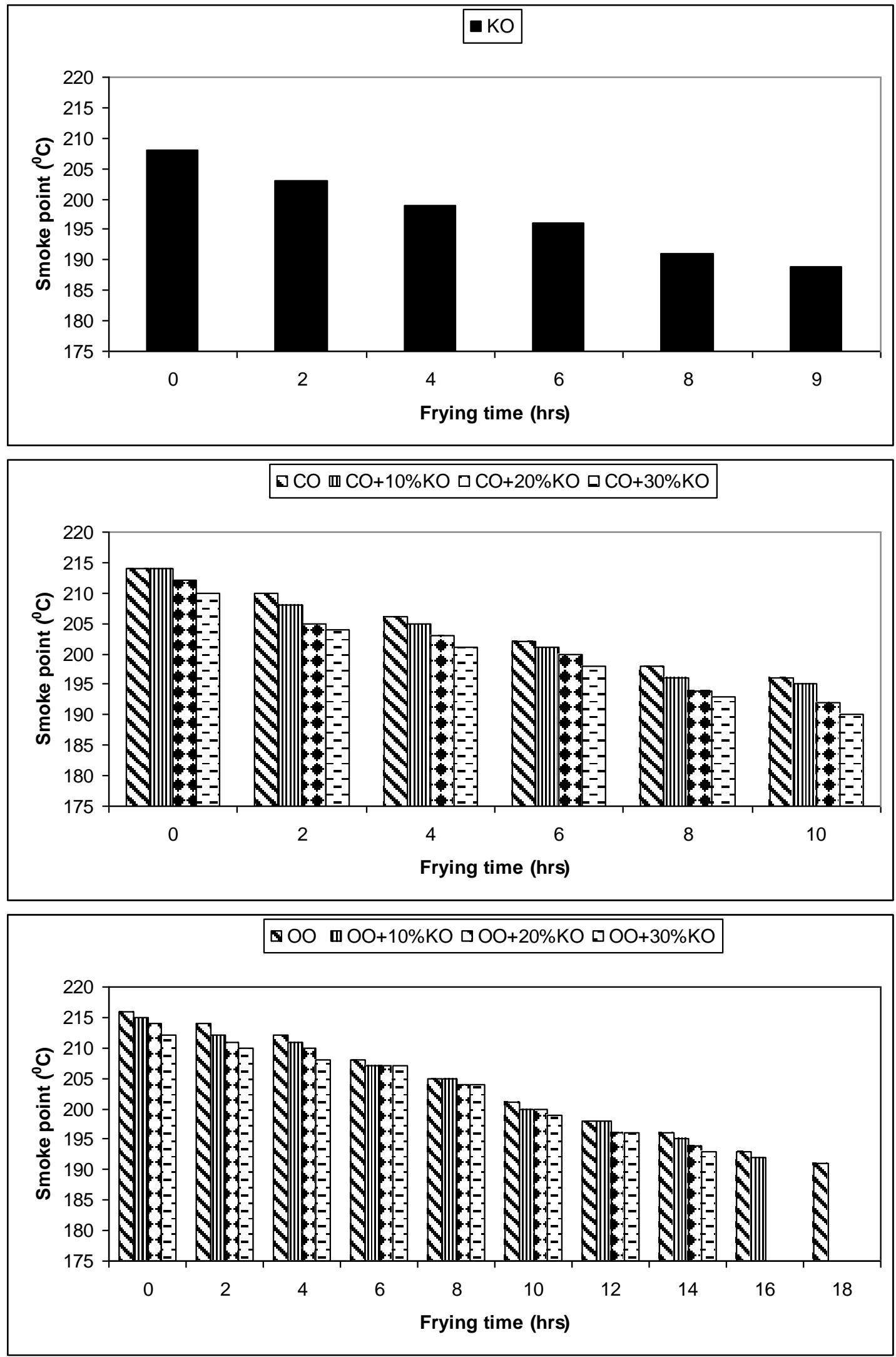

Fig. (4): Effect of frying time on smoke point of the studied oils. (Kenaf seed oil = KO, Cotton seed oil $=$ CO, Olein oil $=$ OO). 


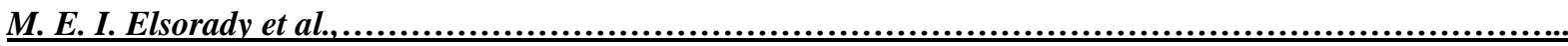

Table (4): Effect of frying time on smoke point of the studied oils.

\begin{tabular}{|c|c|c|c|c|c|c|c|c|c|}
\hline \multirow{3}{*}{$\begin{array}{c}\text { Frying } \\
\text { time } \\
\text { (hrs) }\end{array}$} & \multirow{2}{*}{$\begin{array}{c}\begin{array}{c}\text { Kenaf oil } \\
(\mathrm{KO})\end{array} \\
\text { KO } \\
\end{array}$} & \multicolumn{4}{|c|}{ Cotton seed oil (CO) } & \multicolumn{4}{|c|}{ Olein oil (OO) } \\
\hline & & $\mathrm{CO}$ & $\mathbf{A}^{*}$ & $\mathbf{B}^{*}$ & $\mathrm{C}^{*}$ & OO & $\mathbf{D}^{* *}$ & $\mathbf{E}^{* *}$ & $\mathbf{F}^{* *}$ \\
\hline & \multicolumn{9}{|c|}{ Smoke point $\left({ }^{\circ} \mathrm{C}\right)$} \\
\hline $\mathbf{0}$ & 208 & 214 & 214 & 212 & 210 & 216 & 215 & 214 & 212 \\
\hline 2 & 203 & 210 & 208 & 205 & 204 & 214 & 212 & 211 & 210 \\
\hline 4 & 199 & 206 & 205 & 203 & 201 & 212 & 211 & 210 & 208 \\
\hline 6 & 196 & 202 & 201 & 200 & 198 & 208 & 207 & 207 & 207 \\
\hline 8 & 191 & 198 & 196 & 194 & 193 & 205 & 205 & 204 & 204 \\
\hline 9 & 189 & & & & & & & & \\
\hline 10 & & 196 & 195 & 192 & 190 & 201 & 200 & 200 & 199 \\
\hline 12 & & & & & & 198 & 198 & 196 & 196 \\
\hline 14 & & & & & & 196 & 195 & 194 & 193 \\
\hline 16 & & & & & & 193 & 192 & & \\
\hline 18 & & & & & & 191 & & & \\
\hline
\end{tabular}

enough to permit their aggregation to colloidal sized particles (Tsakins et al., 1999).

As expected, a decrease of the smoke point of the oils during frying was observed. The initial smoke points of olein, cotton seed and kenaf seed oils were 216,214 and $208{ }^{\circ} \mathrm{C}$, decreased to 191,196 and $189^{\circ} \mathrm{C}$ after frying of 18,10 , and 9 hours, respectively. The smoke point depends almost entirely on the FFA content and the molecular weight of the fatty acids. Because it started with the lowest FFA level (Fig. 1), Olein oil had the highest (best) value during 18 frying hours. Kenaf seed oil with the higher FFA level had the lowest value in spite it was fried for only 9 hours.

Because of thermal decomposition of oil during frying, free fatty acids (FFA) and other volatile and degradation oils leave the oil as gases and appear as smoke. The increase in FFA causes a considerable decrease in the smoke point of oils, resulting in a significant fire risk. For safety reasons, the temperature of the frying oil should be kept below its smoking point (McSavage and Trevisan, 2001).

\subsubsection{Fatty acid composition}

The fatty acid composition of kenaf seed, cotton seed, olein oils and their blends are shown in Table (5). The results of kenaf seed oil revealed that $\mathrm{C}_{18: 2}$ is the major fatty acid (46.06\%), followed by $\mathrm{C}_{18: 1}(26.55 \%), \mathrm{C}_{16: 0}$ $(19.26 \%), C_{18: 0}(3.48 \%)$ and $C_{18: 3}(0.9 \%)$. These results agree with those obtained by Coetzee $e t$ al. (2008). Also, kenaf seed oil had the highest amount of $\mathrm{C}_{16: 1}(0.68 \%)$.

Cotton oil contained the greatest amount of $\mathrm{C}_{18: 2}$ and $\mathrm{C}_{18: 3}$ acids (55.1, 2.35\%, respectively) and the lowest amount of $\mathrm{C}_{16: 0}(14.42 \%)$. Also, it had the highest amount of unsaturated fatty acids $(80.86 \%)$. Olein oil had the highest level of oleic acid $(43.44 \%)$ as compared with the other oils. Olein oil had the lowest values of $\mathrm{C}_{18: 2}$ and $\mathrm{C}_{18: 3}$ (11.44 and $0.25 \%$, respectively).

In general, it can be observed from the results of the gas liquid chromatography in Table (5) that the values of $\mathrm{C}_{14: 0}, \mathrm{C}_{16: 0}, \mathrm{C}_{18: 0}, \mathrm{C}_{20 ; 0}$ and SFA (saturated fatty acids) were increased with heating. In contrast, the values of $\mathrm{C}_{18: 3}, \mathrm{C}_{18: 2}$ and USFA (unsaturated fatty acid) were decreased.

The changes in fatty acid composition of the studied oils during frying at $180{ }^{\circ} \mathrm{C}$ are given in Table (5). It was found that there was a decrease in both linolenic $\left(\mathrm{C}_{18: 3}\right)$ and linoleic $\left(\mathrm{C}_{18: 2}\right)$ acids, whereas palmitic acid $\left(\mathrm{C}_{16: 0}\right)$ was increased with frying time across. The decrease in $\mathrm{C}_{18: 2}$ was mainly due to the oxidation of unsaturated fatty acid into primary and secondary oxidation products, which decreased the percentage of unsaturated fatty acid composition. Linoleic and palmitic acids are usually used as indicators of the extent of fat deterioration because linoleic acid is more susceptible to oxidation, whereas palmitic acid is more stable toward oxidation. Therefore, the ratio of $\mathrm{C}_{18: 2} / \mathrm{C}_{16: 0}$ was also used to indicate the degree of oxidative deterioration of frying oil. The ratios of $\mathrm{C}_{18: 2} / \mathrm{C}_{16: 0}$ are presented in Table (5). In all of the studied oils, these ratios declined rapidly across the end of frying. These results agree with Che Man and Tan, (1999).

\subsection{Oil-uptake}

Oil adsorption by potatoes (Table 6) is quite similar for the three oils at $1^{\text {st }}$ fry $(28.15,29.10$, and $33.5 \%$ ) for kenaf seed, cottonseed and olein oils, respectively ). These findings are in agreement with the data reported by Vitrac, 
Table (5): Changes in fatty acid composition of the studied oils during frying at $180 \pm 5^{\circ} \mathrm{C}$.

\begin{tabular}{|c|c|c|c|c|c|c|c|c|c|c|c|c|c|c|c|c|c|c|}
\hline \multirow{4}{*}{$\begin{array}{l}\text { Fatty } \\
\text { acids }\end{array}$} & \multirow{2}{*}{\multicolumn{2}{|c|}{$\begin{array}{c}\begin{array}{c}\text { Kenaf oil } \\
(\mathrm{KO})\end{array} \\
\text { KO } \\
\end{array}$}} & \multicolumn{8}{|c|}{ Cotton seed oil (CO) } & \multicolumn{8}{|c|}{ Olein oil (OO) } \\
\hline & & & \multicolumn{2}{|c|}{$\mathrm{CO}$} & \multicolumn{2}{|c|}{ A* } & \multicolumn{2}{|c|}{ B* } & \multicolumn{2}{|c|}{ C* } & \multicolumn{2}{|c|}{$\mathbf{O O}$} & \multicolumn{2}{|c|}{ D** } & \multicolumn{2}{|c|}{$\mathbf{E}^{* *}$} & \multicolumn{2}{|c|}{$\mathbf{F}^{* *}$} \\
\hline & \multicolumn{18}{|c|}{ Frying Time (hrs) } \\
\hline & $\mathbf{0}$ & 9 & $\mathbf{0}$ & 10 & $\mathbf{0}$ & $\mathbf{1 0}$ & $\mathbf{0}$ & $\mathbf{1 0}$ & $\mathbf{0}$ & 10 & $\mathbf{0}$ & 18 & $\mathbf{0}$ & 16 & $\mathbf{0}$ & 14 & $\mathbf{0}$ & 14 \\
\hline $\mathrm{C}_{8: 0}$ & 0.00 & 0.18 & 0.00 & 0.00 & 0.00 & 0.00 & 0.00 & 0.00 & 0.00 & 0.00 & 0.02 & 0.12 & 0.00 & 0.04 & 0.00 & 0.19 & 0.01 & $\mathbf{0 . 0 2}$ \\
\hline $\mathrm{C}_{12: 0}$ & 0.03 & 0.00 & 0.00 & 0.00 & 0.00 & 0.00 & 0.00 & 0.00 & 0.00 & 0.00 & 0.21 & 0.28 & 0.11 & 0.27 & 0.17 & 0.20 & 0.16 & 0.05 \\
\hline$C_{14: 0}$ & 0.15 & 0.16 & 0.22 & 0.28 & 0.28 & 0.37 & 0.12 & 0.13 & 0.25 & 0.34 & 0.94 & 1.21 & 0.76 & 1.14 & 0.80 & 0.87 & 0.75 & 0.53 \\
\hline $\mathrm{C}_{16: 0}$ & 19.26 & 22.68 & 14.24 & 17.32 & 14.29 & 19.54 & 11.95 & 14.76 & 15.51 & 19.50 & 38.31 & 51.31 & 36.37 & 47.52 & 35.39 & 40.89 & 34.16 & 35.34 \\
\hline$C_{16: 1}$ & 0.68 & $\mathbf{0 . 8 0}$ & 0.45 & 0.54 & 0.46 & $\mathbf{0 . 5 8}$ & 0.29 & 0.43 & 0.45 & 0.53 & 0.34 & 0.54 & 0.32 & $\mathbf{0 . 5 0}$ & 0.39 & 0.45 & 0.39 & 0.55 \\
\hline$C_{17: 0}$ & 0.09 & 0.09 & $\mathbf{0 . 0 0}$ & $\mathbf{0 . 0 0}$ & 0.00 & 0.00 & 0.00 & 0.00 & 0.00 & 0.00 & 0.08 & 0.16 & 0.09 & 0.17 & 0.09 & 0.11 & 0.09 & 0.13 \\
\hline$C_{17: 1}$ & 0.18 & 0.18 & $\mathbf{0 . 0 0}$ & 0.00 & 0.00 & 0.00 & 0.00 & 0.00 & 0.00 & 0.00 & 0.03 & $\mathbf{0 . 0 3}$ & 0.04 & 0.02 & 0.07 & 0.06 & 0.08 & 0.09 \\
\hline$C_{18: 0}$ & 3.48 & 2.93 & 3.64 & 4.15 & 3.62 & 4.51 & 3.94 & 4.39 & 3.75 & 4.22 & 4.12 & 5.50 & 4.16 & 5.15 & 4.09 & 4.37 & 4.02 & 4.36 \\
\hline $\mathrm{C}_{18: 1}$ & 26.55 & 28.56 & 22.72 & 27.21 & 23.85 & 28.81 & 25.48 & 29.27 & 24.27 & 27.60 & 43.44 & 34.20 & 43.37 & 35.90 & 41.31 & 39.49 & 40.32 & 38.88 \\
\hline $\mathrm{C}_{18: 2}$ & 46.06 & 35.72 & 55.10 & 44.24 & 54.20 & 43.08 & 55.04 & 46.53 & 53.13 & 44.49 & 11.44 & 2.05 & 13.66 & 3.25 & 16.92 & 9.38 & 19.21 & 11.79 \\
\hline $\mathrm{C}_{18: 3}$ & 0.90 & 1.33 & 2.35 & 1.43 & 2.19 & 0.66 & 2.04 & 1.40 & 1.84 & 1.15 & 0.25 & 0.01 & 0.26 & 0.11 & 0.28 & 0.17 & 0.29 & 0.13 \\
\hline$C_{20: 0}$ & 0.42 & 0.86 & 0.42 & 0.67 & 0.41 & 0.64 & 0.43 & 0.74 & 0.33 & 0.72 & 0.34 & 0.49 & 0.37 & 0.67 & 0.36 & 0.29 & 0.37 & 0.77 \\
\hline $\mathbf{C}_{20: 1}$ & 0.05 & 1.25 & 0.24 & 1.33 & 0.23 & 1.31 & 0.19 & 1.71 & 0.11 & 0.99 & 0.16 & 0.17 & 0.17 & 0.26 & 0.15 & $\mathbf{0 . 5 3}$ & 0.14 & 0.36 \\
\hline $\mathrm{C}_{22: 0}$ & 0.00 & 0.00 & 0.53 & 0.64 & 0.46 & 0.50 & 0.51 & 0.64 & 0.36 & 0.43 & 0.00 & 0.00 & 0.00 & 0.00 & 0.00 & 0.00 & 0.00 & 0.00 \\
\hline SFA $\%$ & 23.43 & 26.90 & 19.05 & 23.06 & 19.06 & 25.56 & 16.95 & 20.66 & 20.20 & 25.21 & 44.02 & $\mathbf{5 9 . 0 7}$ & 41.86 & 54.96 & 40.90 & 46.92 & 39.56 & 41.20 \\
\hline USFA \% & 74.42 & 67.84 & 80.86 & 74.75 & 80.93 & 74.44 & 83.04 & 79.34 & 79.80 & 74.76 & 55.66 & 37.00 & 57.82 & 40.04 & 59.12 & $\mathbf{5 0 . 0 8}$ & 60.43 & 51.80 \\
\hline$C_{18: 2}: C_{16: 0}$ & 2.39 & 1.26 & 3.82 & 2.55 & 3.62 & 2.20 & 4.61 & 3.15 & 3.43 & 2.28 & 0.30 & 0.04 & 0.38 & 0.07 & 0.48 & 0.23 & 0.56 & $\mathbf{0 . 3 3}$ \\
\hline
\end{tabular}


Table (6): Effect of frying at $180 \pm 5^{\circ} \mathrm{C}$ on oil uptake of potato samples.

\begin{tabular}{|c|c|c|c|c|c|c|c|c|c|}
\hline \multirow{3}{*}{ Frying time (hrs) } & \multirow{2}{*}{$\begin{array}{c}\begin{array}{c}\text { Kenaf oil } \\
\text { (KO) }\end{array} \\
\text { KO }\end{array}$} & \multicolumn{4}{|c|}{ Cotton seed oil (CO) } & \multicolumn{4}{|c|}{ Olein oil (OO) } \\
\hline & & $\mathrm{CO}$ & $\mathbf{A}^{*}$ & B* & $C^{*}$ & OO & $\mathbf{D * *}$ & $\mathbf{E}^{* *}$ & $\mathbf{F}^{* *}$ \\
\hline & \multicolumn{9}{|c|}{ Oil Uptake (g / 100g ) } \\
\hline $0\left(1^{\text {st }}\right.$ fry $)$ & 28.15 & 29.10 & 28.90 & 28.61 & 28.50 & 33.50 & 33.04 & 32.5 & 31.2 \\
\hline 9 & 51.59 & & & & & & & & \\
\hline 10 & & 54.12 & 54.30 & 54.38 & 54.45 & & & & \\
\hline 14 & & & & & & & & 48.61 & 51.42 \\
\hline 16 & & & & & & & 59.82 & & \\
\hline 18 & & & & & & 60.77 & & & \\
\hline
\end{tabular}

(2000) who showed that oil uptake is weaker with an unsaturated oil such as cotton oil than with palm oil because of the former's weak viscosity during cooling and its ability to drain easily.

On the other hand, Kita and Lisinska (2005) found that fat absorption is higher when the amount of unsaturated fatty acid increases in oil. Oil uptake was increased with an increase of frying time.

The largest part of the oil is taken up only at the end of deep-fat frying when the potato samples were removed from the fryer (Alim and Morton, 1974). The relationship between frying oil-uptake and the contact angle between the frying medium (the oil) and the potato product was discussed by Pinthus et al. (1993). It was reported that the decrease in the contact angle is related to the formation of "oxidized macro molecules" during deep-fat frying that are more polar than native triglycerides (Blumenthal, 1991; Pinthus and Saguy, 1994). These molecules are considered to have surface activity, to reduce interfacial tensions and to improve wetting (expressed in reducing contact angles) (Pinthus and Saguy, 1994). The decrease in contact angle allows longer contact times between the hot oil and the aqueous food surfaces, and results in increased oil uptake by foods (Pinthus and Saguy, 1994).

From the obtained results in this study, it can be concluded that kenaf seed oil had similar properties like cotton seed oil and can be used in frying. Further biological studies are essential to detect the complete safety of kenaf seed oil for human nutrition.

\section{REFERENCES}

Abdel-Aal M.H. and Karara H.A. (1986). Changes in corn oil during deep-fat frying of foods. Lebensm.-Wiss. Technol. 19, 323-327.
Alim H. and Morton I. D.(1974). Oxidation in foodstuffs fried in edible oils. In Proceedings of the IV International Congress of Food Science and Technology. Instituto National de Ciencia y Technologia de Alimentos, Consejo Superior de Investigaciones Cienti"cas, Madrid, Spain, I, pp. 345-356.

Allen J.C. and Hamilton R. (1989). Rancidity in Foods. $2^{\text {nd }}$ ed. El Sevier Applied Science, London and N.Y.

AOAC (2005). Official methods of Analysis of AOAC International $18^{\text {th }}$ ed. Gaithersburg, Maryland, USA.

AOCS (1998). Official and tentative methods of the American oil chemists society (5th ed.). American Oil Chemists Society, 35 East Waker Drive, Chicago, Illinois, USA.

Ather M. and Mahmood S. N. (2005). Taxonomic perspective of plant species yielding vegetable oils used in cosmetics and skin care product. Afr. J. Biotechnol., 4 (1): $36-44$

Blumenthal M. M. (1991). A new look at the chemistry and physics of deep-fat frying. Food Technology, 45, 68-71.

Charles L. W., Venita K. B. and Robert E. B. (2002). Kenaf harvesting and processing In: "Trends in new crops and new uses" (eds Janick, J. and Whipkey, A..), ASHS Press, Alexandria, VA. pp. 340-347.

Che Man Y.B. and Tan C.P. (1999). Effects of natural and synthetic antioxidants on changes in refined, bleached, and deodorized palm olein during deep-fat frying of potato chips. JAOCS, Vol. 76, no. 3, 331-339.

Chifundera K., Balagizi K, and Kizungu B. (1994). Les empoisonnements et leurs antidotes en medicine traditionnel au Bushi, Zaire. Fitoterapia., 65: 307-313.

Clark W. T. and Serbia G. W. (1991). Safety 
aspects of frying fats and oils. Food Technol., 45: 84-89, 94.

Codex (2004). Food chemicals codex/ committee on Food Chemical Codex, Food and Nutrition Board (5th ed). The national Academics Press, Washington, D.C.

Coetzee R., Lebuschagne M.T. and Hugo A. (2008). Fatty acid and oil variation in seed from kenaf (Hibiscus cannabinus L.). Ind. Crops Prod., 27 (1): 104-109.

Cossignani L., Simonetti M.S. and Damiani P. (2005). Biocatalyzed acidolysis of olive oil triacylglycerols with $9 c, 11 t$ and $10 t, 12 c$ isomers of conjugated linoleic acid. Eur. Food Res. Technol., 220, 267271.

Cuesta C., Sanchez-Muniz F. J. and Hernandez, I. (1991). Evaluation of nonpolar methyl esters by column and gas chromatography for the assessment of used frying olive oils. Journal of the American Oil Chemists' Society, 68, 443- 445.

Dobarganes M. C, Perez-Camino M. C. and Marquez-Ruiz, G. (1988). High performance size exclusion chromatography of polar compounds in heated and non heated fats. Fat Sci. Technol. 90, 308-311.

El-Daly M. A. A. (1970). Chemical and nutritional studies on kenaf seeds (Hibiscus cannabinus L.), M. Sc. Thesis. Department of Chemistry, Faculty of Agriculture, Cairo University, Cairo, Egypt.

Fritch C.W.(1981). Measurements of frying fat deterioration: A brief review. Journal of the American Oil Chemists' Society, 58, 272-274 .

Gião A. N. S. V., Mattos E. S. and Jorge N. (1999), Avaliação da qualidade dos óleos de fritura usados em restaurantes, lanchonetes e similares. Ciência e Tecnologia de Alimentos, 19(3), 1-15.

Gil B., Cho Y. J. and Yoon S. H. (2004). Rapid determination of polar compounds in frying fats and oils using image analysis. Lebensm Wiss u Technol., 37: 657-661.

Gutirrez R., Gonzalez O. and Dobarganes M.C.(1988). Analytical procedures for the evaluation of used frying fats. In Frying Food: Principles, Changes, New Approaches (G. Varela, A.E. Bender and I.D. Morton, eds.) pp. 141-154, VCH Publishers Ltd, London, England.
Hussein I. H., Mirghani M. E. S. and Che Man, Y. B. (2006). Physicochemical characteristics of Argessi ( Chrozophora brochiana), Kenaf (Hibiscus cannabinus L. ) and Loofah ( Luffa cylindrica) seed oils. Sudan. J. Agric. Res., 6: 53-60.

Innawong B., Mallikarjunan P. and Marcy J.E. (2004). The determination of frying oil quality using a chemosensory system. Lebensm Wiss u Technol., 37: 35-41.

Jacobson G.A. (1967). Quality control of commercial deep fat frying. Food Technology 21 (2): $43-48$.

James C. S. (1995). Analytical chemistry of food. Seale-Hayne Faculty of Agriculture, Food and Land use Departement of Agriculture and Food studies, University of Plymouth, UK., 1 : 96-97.

Kita A. and Lisinska G. (2005). The influence of oil type and frying temperatures on the texture and oil content of French fries. Journal of the Science of Food and Agriculture, 85, 2600-2604.

Mc-Savage J. and Trevisan S. (2001). Use and abuse of frying oil. In: Culinary Arts and Sciences III, Editors: J.S.A. Edwards \& M.M. Hewedi, Cairo, Egypt.

Melton S. L., Jafar S., Sykes D. and Trigiano M. K. (1994). Review of stability measurements for frying oils and fried food flavor. Journal of the American Oil Chemists' Society, 71, 1301-1308.

Mohamed A., Bhardwaj H., Hamama A. and Webber C. (1995). Chemical composition of kenaf (Hibiscus cannabinus L. ) seed oil . Ind. Crops Prod., 4: 157-165.

Pantzaris T. P. (1998). Comparison of monounsaturated and polyunsaturated oils in continuous frying .Grasas y Aceites, 49, 319-325.

Peeled N., Gutfinger T. and Letan, A. (1975). Effect of water and BHT on stability of cottonseed oil during frying. J. Food Sci. Agric. 26, 1655-1668.

Pinthus E. J. and Saguy I. S.(1994). Initial interfacial tension and oil uptake by deepfat fried foods. Journal of Food Science, 59, 804-807 and 823 .

Pinthus E. J.,Weinberg P. and Saguy I. S. (1993). Criterion for oil uptake during deep-fat frying. Journal of Food Science, 58, 204- 222.

Rasit R., and Augustin M.A. (1982). Effect of tertiary-butylhydroquinone on the stability of fried banana chips, Pertanika 5:119-122 . 
Reed C. F. (1976). Information summaries on 1000 economic plants. Typescripts submitted to USDA. Cited by Duke (1983).

Sati Y. A. A., Ahmad H. A. and Etab T. A.(2011). Effect of aromatic plant essential oils on oxidative stability of sunflower oil during heating and storage. Pakistan Journal of Nutrition 10 (9): 864870.

Tsakins J. and Lalas S. (2002). Stability during frying of Moringa oleifera seed oil variety "Periyakulam 1." J. Food Compos. Anal. 15, 79-101.

Tsakins J., Spiliotis V. Lalas S., Gergis V. and Dourtoglou, V. (1999): Quality changes of Moringa oleifera, variety Mbololo of Kenya, seed oil during frying .Grasas y Aceites, 50, 37-48.

Tyagi V. K. and Vasishtha A. K. (1996).
Changes in the characteristics and composition of oils during Deep-fat frying. J. Amer. Oil Chem. Soc., 73: 499506.

Varela G. and Ruiz-Roso B. (1992). Some effects of deep frying on dietary fat intake. Nutr. Rev., 50: 256-262.

Vitrac O. (2000). Caractérisation expérimentale et modélisation de l'opération de friture. Ecole Nationale Supérieure des Industries Agricoles et Alimentaires, Massy, France. Ph..D Thesis, $262 \mathrm{p}$.

Webber C. L., Bhardwaj H. L. and Bledsoe V. K. (2002). Kenaf production : fiber, feed, and seed. In : " Trends in new crops and new uses" (eds Janick, J. and Whipkey, A..), ASHS Press, Alexandria, VA. pp. 327-339.

White P. J. (1991). Methods for measuring changes in deep-fat frying oils. Food Technol., 45: 75-80. 